\title{
An Interview with Donald Justice
}

TIR: Let's begin by asking about Selected Poems because that, after all, is the occasion for this interview. We'd like you to tell us something of how it came together out of your other collections. In the notes at the back you describe its arrangment as a "fair chronological order." That's a curious qualification. DJ: I didn't realize that would be ambiguous. I meant "approximately." After so long it's difficult to know exactly when you wrote something. I didn't want to say the poems were arranged in chronological order because I couldn't be quite sure of that. But as well as I could reconstruct the history of it these are in order. In some cases I'm positive of the sequence because it meant something to me at the time.

TIR: Do you keep notebooks and dated papers?

DJ: I do now but I didn't in the past. I've become more compulsive instead of less. In quite a few cases I can remember where or when I wrote a certain poem. One poem I remember writing on Memorial Day, 1954. We were supposed to go to a couple of parties and I kept saying, "Let's wait until I finish this, it won't be long now." It took me all day and well into the night, so we didn't make the parties.

TIR: You can probably remember when you wrote a poem more easily than many other things.

DJ: Perhaps. But I do generally remember where and when I saw movies, for instance, and I can remember where I read most novels. I read Madame Bovary in the railroad station in Portland, Maine.

TIR: Sometimes you have remembered very precisely, as with, for example, the poem "Fragment: To a Mirror," which has two dates, '63-'72. Was that one you returned to and finished?

DJ: Yes. I had started it in 1963. I keep notes while working on poemsphrases, lines, passages, perhaps only words -if anything at all seems promising in the project. I had gone back to the notes for this one more than once to try to make something out of them. And finally, when preparing Departures, I just decided I would do what I could with those old notes, and if I couldn't do anything I'd throw them away. They'd been around long enough. I left out a great deal of the ambitious scaffolding for the poem but did get it whittled down to what I could accept.

TIR: When you say you keep notes...

DJ: I mean all the paper that has been written or scribbled on while working out the poem.

I had a remarkable experience once. I was working on a poem that wasn't

Conducted by David Hamilton and Lowell Edwin Folsom August 19, 1980 
going anywhere, but once in a while you can rescue something from the wreckage of the notes. I'd been fiddling with this particular poem off and on for two or three years, and one night I made a little progress. So when I was free to work on it again, three or four nights later, I looked around for the notes containing those small advances. I couldn't find them. I'd spent thirty minutes looking for them, I guess, when I gave up and decided to start back at the point I'd started before. I worked perhaps till midnight and again made a little progress. Well, the next time I came to work on the poem, I found both sets of notes and they were almost identical, almost word for word, including scratchings out. "Oh," I thought, "I'm really doing marvellously well on this poem; I must have found what has to be done." I have a sort of Platonic notion that somewhere ideally exists the poem I'm trying to write, if only I can find it, and here I had this excellent testimony, a sign that I was on the right track. As it happens, I finished the poem and it wasn't very good. I published it, but it's not in Selected Poems. I had been mistaken, you know; the signs were wrong. Very disappointing, considering all the work I put into it, and the sign. TIR: I picture lots of papers around, in cardboard boxes and desk drawers. DJ: Boxes, and now I have a fine filing cabinet that I've been picking through in preparation for going away for the year. Yes, it has a lot of stuff in it. And I've thrown things away as well.

TIR: One of the things you have to do now is decide which poems to take along.

DJ: Yes, that's right, and that was interesting. I'm taking five poems and four plays. Plays are what I want to try to work on this year, but I have a few poems too that I haven't quite finished.

TIR: Are any of these poems of Tremayne? We've seen three of those, two in Selected Poems and another in The New Yorker. They suggest a series.

DJ: That most recent Tremayne poem is one that was left over from Selected Poems; I hadn't been able to finish it. There was meant to be a group of four poems, and two of them simply weren't finished in time for the book. In a fourth Tremayne poem, still not done, I have, maybe, twenty versions of the last stanza, and I'm not satisfied. I'd like to get it out of the way. I've spent more than enough time on it already and probably should settle for one of the versions I have, but I know there is something better.

What I seem to have been doing this year is simply trying to finish whatever I could not finish before. Actually that seems to be the condition I'm often in, and not just after a book. There always seem to be notes and bits of things and fragments lying around and I keep trying to complete them, put them together. It's a little bit like-I don't know whether you have this compulsion or not-trying to make the meat and the bread come out together. If you don't, you have to take a little bit more of one or the other. Well, there always seem to be notes spilling over from poems just finished. An endless process, thank goodness. 
TIR: When did you know the Tremayne poems were going to be a series of four?

DJ: Early. Four happens to be one of those literary numbers, like three or nine. I noticed that in the first couple of Tremaynes, seasons were mentioned. And I thought, "Ah ha, one for each season." Someone with the predictable sense of design I have is always looking for ways to make things go together, and a set of seasons adding up to four would make the kind of obvious sense that appeals to me. It turned out that the third one didn't have anything to do with a season; nevertheless that was part of the idea.

TIR: It spoke of seasons of the day: "And something starts all over, call it day." DJ: Right but ... the last one, what I think will be the last one-I don't know, if I enjoy doing them and have another workable idea I wouldn't necessarily keep to my own rule-but the fourth and last one I intend to write is about autumn.

TIR: I'm curious about your decision when putting together Selected Poems to move to chronological order as opposed to whatever were the ordering principles of the other volumes. What guided that shift?

DJ: I'm not sure. I know I had organized my other books by considering two factors: subject or theme, and form or type or genre. In the first book, for instance, I put all the sestina-like poems together. In another part I put together a number of poems dealing with madness. That at least was my principle. But in combining three books and the uncollected poems I found myself backtracking again and again to some of the same topics, and I didn't think it would make very good sense to put all the poems on childhood together, say, dating from the early fifties to the late seventies. And I didn't want to put all the rhymed poems together, or all the syllabics together. It seemed wrong somehow. So, it occurred to me that others had arranged their selections in chronological order, and I had really been interested in seeing history unfold itself, so to speak, in their work. I tried it and it seemed to make good sense, even perhaps to reveal something. I have had letters from friends saying that they hadn't seen so clearly before how the books seemed to follow from one another, or how all of them seemed more of a piece than they had supposed. If that's the impression, good; I was lucky to have chosen a chronological order.

TIR: That choice touches on your fascination with memory; it allows us to see the book itself as a kind of chronology, less of your life than of your memory.

DJ: Yes, I hadn't thought of that and I would be happy if that were true. It may be.

TIR: It would seem that one of the ways that you could tamper with things if you're going to make a chronological order is by omission. You could heighten a connection or a sense of thematic closeness by leaving something out. 
DJ: I didn't leave things out for that reason. I left things out because I didn't like them any longer. They had failed to achieve their intention or were written in a style I had become unwilling to acknowledge as mine.

TIR: Obviously that must be true, but it did strike us that the other kind of tinkering could be hovering on the margins of things. To leave the "ABC" poem out of Departures, for example, allowed you to put "Fragment" first, which emphasizes a very different theme in that book.

DJ: Not intentionally. "ABC" was much influenced by Continental poetry, particularly French. Postwar French poets seemed to have, as I read them, one dominant theme, which was poetry itself. I read a fair amount of the poetry from that period, translated some of it, and became hung up on the theme myself. "ABC" is in part a product of that. But it came to seem to me not a theme I wanted much to do with after all. I was grandiloquent in that poem, I thought, and I didn't like that. I left out at least one other poem on the art of poetry, a poem from my first book, entitled "Thus." It was a nice exercise in a way, but it didn't really represent the way I felt about the case. I still have some left-over notes for "ABC" around, I think, because that was a poem that took a great many pages to write. Some of the metaphors I generated by whatever means I was using-I was using a variety of means-were unbelievable. At least I couldn't believe in them.

TIR: "Variety of means," could you itemize?

DJ: Well, one of the things I was doing at the time was using my all too notorious cards.

TIR: Chance methods?

DJ: Yes. And another thing I was doing-I don't know how to describe this method, if it's a method, and yet it's something others have done too-was conscientiously to mistranslate. I don't know quite how to explain what you do, but you might say that you worry more about getting it interesting than about getting it right. If a word in French suggests a word you like, you're quite willing to use it even though it's not what the French means. It's a way of displacing the mental attention, which I think is often fruitful in composition. If you can look not straight at the object, but from an angle, you see it differently. I had a student in California, a very talented student, who claimed he had nothing to write about. And I asked if he knew French. He did. "Well," I said, "do you know Spanish?" He did not. And I suggested he get a book of poems in Spanish, the language he did not know, and translate them. That afternoon he wrote twenty or so poems, and perhaps seven or eight of them were beautiful-I've never seen the method work so well for anybody else. I don't think he uses it any more, but it was like a small revelation, that once. I think it might work for anybody, on a lucky afternoon.

TIR: That suggests something about faith in the riches of the mind, doesn't it? 
DJ: Yes, you have to have something - a certain character, say-to bring to whatever method or process you're using and you have to have a certain facility, but if you've got those you don't have to write directly about whatever may seem to be deepest in your soul. Whatever that is, if it is strong and true, will come out anyway.

TIR: Can you think of times when you tried to write directly about what you thought was deepest in your soul?

DJ: I cannot remember a time when I tried that, I'm sorry to say. Not certainly since adolescence.

TIR: We were wondering about changes in Selected Poems. Not only were the poems reordered, several were revised. In "The Confession," the first stanza now reads, "You have no name, intimate crime;/ There is nothing to whisper./ You have fled across many pillows,/ But you leave nothing behind." Originally it was, "You have no name, intimate crime,/ Into which I might plunge my hand./ Your knives have entered many pillows,/ But you leave nothing behind."

DJ: I found those two images somewhat melodramatic-maybe they were appropriate to the crime itself-but I felt they were mannered in a popularly surreal sense. I wanted to make them quieter while keeping the same argument. Also one or two people who had taken the trouble to speak of that stanza had been slightly confused by the images. I didn't think they were unclear or I wouldn't have written them in the first place, and I might have been willing to simplify in the interest of clarity alone if I had not been even more strongly motivated by this desire to cut down on the melodrama and the manneristic surrealism of the images. I myself think the surreal image is most powerful when it is rooted in the real.

TIR: Another revision I wanted to ask you about was "Sonatina in Yellow," a poem I'm very fond of.

DJ: What did I change, the end?

TIR: Right. Originally it was, "Repeat it now, no one was listening./ Repeat it, the air, the variations."

DJ: Ah, yes.

TIR: Why did you remove the line, "Repeat it, the air, the variations"?

DJ: Well, I always had had trouble with what I think of as the coda of this poem, the last little paragraph. Now what it should do, I felt from the start, was repeat or take up again motives, or motifs even, to speak of the question musically, from what had gone before. Now the "air" is a pun on the dead air of summer mentioned earlier in the poem and also on a musical air. That much is obvious. The "variations" would have to do with musical form as well-also of course with the verbal variations on the phrases and as a consequence on the themes that appear earlier in the poem. In that sense it fitted in the coda, but it seemed to me that it slowed things down a good deal. It was 
in there merely for a sort of formal reason. It was doing its job. And I wanted whatever I had in there at the end to be doing more than its job. I'm glad you like the poem, because I like it too, but I'm worried about some of its features. Particularly there at the end. When I first sent in the text for the book, the "Repeat it now" line was also gone. Finally I thought I needed one "repeat" line but not two. Who knows? Listen, the first time I finished this poem, there were crows flying around through several of the stanzas.

TIR: And you got all the crows out.

DJ: And kept them out.

TIR: It seems like a willful thing to do, putting crows in a sonatina in yellow. DJ: Well, the poem is in a way about death, and they seemed to me, with their blackness, to associate very well with that. Also their harsh music. But they were too symbolical really.

One of the things I was wondering about taking south with me was the notes on this poem. I haven't given up on this. It has a prose commentary intended to accompany the verse text which I haven't shown to anybody. Still, I decided finally to leave all this behind in the filing cabinet. I didn't want to get hung up on that again. I've spent a lot of time on this poem and on the other sonatina and on a couple of others I haven't published. But one day I may get it right, in which case it will have a prose commentary, and that prose commentary will describe a descent into the underworld, a legendary sort of descent. Because that is implied in this poem. The prose commentary will bring out undertones and make them much stronger perhaps. All speculative, of course. TIR: So when you come to offering a prose commentary as in "Childhood," the last poem in the volume, that's not something that you've just happened upon.

DJ: It's an idea I've wanted to put to work for a long time. Once the notion of a prose commentary enters your head, it's hard to get it out. You'd like not only to write the poems but to write the commentary, you know; don't leave that up to the others, who're likely to get it wrong anyhow.

TIR: Do you have models in mind for that kind of writing?

DJ: Coleridge, Hart Crane. But I wasn't able to do it as they did it. I wanted to write elevated, mystical, highly charged prose. I just couldn't screw my courage up to that-or my style, more likely.

TIR: Prose that would be more rhetorical than the poetry?

DJ: Yes, exactly.

TIR: And that would serve as some sort of ironic counterpoint to the poetry? DJ: Yes, in the commentaries on the sonatinas which I have, but which I haven't been able to get right, that is indeed the case. I was reading some of The Bridge marginalia yesterday and it's a prose much more as I would want it, you know, nicely florid and elevated.

And yet I have to acknowledge that one of the afflictions of American verse 
at present is the prose poem, and one reason it is an affliction instead of a salvation is that poets allow themselves all sorts of licenses regarding rhetoric, elevation, diction, and foolish ideas that they wouldn't think of allowing themselves in their so-called verse. I've been saying to my students in the last few years, "Your prose has got to be at least as well-written as your poetry," because most of them really do write their poems more conscientiously than they do their prose. Maybe we've come to another historical moment.

TIR: You've expressed a conviction that there really is no such thing as organic meters, that you can't imitate the sea, breathing, the heartbeat.

DJ: I do think that. I may be wrong, but that is a conviction.

TIR: You also believe that music is the one art that does not have as its motive memory.

DJ: So far as I can experience the arts that is true.

TIR: Given these two convictions, I'm surprised that I find music entering your poetry at the moments of most intense memory.

DJ: I knew you were working up to some sort of paradox.

TIR: In "Memory of a Porch," "I heard / The thing begin / A thin, skeletal music," or in "Absences," "Like the memory of scales descending the white keys." The sonatinas themselves, especially the "Sonatina in Yellow," are intense poems of memory, I think, and your sonatina form apparently tries to imitate music in language.

DJ: I think I can account superficially for what you're pointing out, which I hadn't noticed before. I think it may be because my own memory happens to be rich in memories of music. I have felt very strongly about music at times. So recollections of music come back to me naturally enough sometimes when emotion approaches. I mean quite naturally out of experience, rather than from any theory, involving hierarchies or distinctions among the arts.

TIR: What about the sonatina form then?

DJ: The sonatina form is really very simple. I'd wanted to try a quasi-musical form and the simplest of all among the classical possibilites, it seemed, would be the precursor of the sonata form, the sonatina, in which you only really had to have two parts, two themes. I didn't want to get into a complicated sonata-allegro, even if it could be done. I certainly didn't want to get into any sort of complicated set of quasi-muscial forms such as you find in the "Four Quartets," or think you have found after reading the criticism. It seemed to me that you might wish to start modestly. The sonatina is a modest classical form which involves an A part and a B part. It involves saying A again and saying $B$ again in a key different from the one it was said in the first time around.

The only thing I had to find was an A thing to say and a B thing to say, and-which was trickier - a way to change the key of $B$. The form also allows a little freedom; you can either say A B A B or you can say A B B A or you 
can say A plus transition plus B, you know, or you can put a coda or several codas at the end. There's a little flexibility, a little give. I tried to find a change of key, a modulation, which would be linguistic or grammatical rather than musical. So I worked all these schemes out in advance of writing the poem; that was part of the pleasure of the whole business for me at the time. And it seemed to me that one of the ways of modulating, grammatically, would be to change the tense; another might be to change the person. I've forgotten now, but I worked out four or five of these; I guess one was to change from interrogation to declaration. But then I felt it really wasn't literarily interesting just to repeat $A$ if there were more than two or three lines to it; so I modified A, which also happens in the musical form, at least as it moves toward the sonata-allegro form-you get into development sections.

TIR: It becomes analogous to your way of using translation as a mode of invention, not just in fidelity to the original text.

DJ: Yes, that's true; to think about something else allowed me to write about what I was interested in, but indirectly, from an angle. I hadn't meant when I started "Sonatina in Yellow" to write about my father. But I did have as a general idea in all the sonatinas the mythic or legendary theme of descending into the underworld, and once I began mentally or spiritually or esthetically to descend into the underworld I found my father.

TIR: Had he been dead then for some time?

DJ: For thirteen years. But I hadn't written any poems about him. So I need not have been surprised to find him there.

TIR: Are musical forms generally available to you?

DJ: Not so much what I would call forms-but yes, vaguely musical possibilities, though I think "musical" as a critical term referring to effects of sound in poetry is much overused, abused even. I am interested in the musical sounding of the words in some poems, and in a few places I have gone to some trouble to make these sounds linguistically rich; but I haven't loaded up the sonatinas in this way. They're probably a little more musical in this primitive fashion, that is, in the mere sounding of their words, than most of what I would write, but it's the structure of the music that I was interested in imitating, not otherwise the sound. I would be interested in trying to write something in another musical form sometime. I've tried the blues but that's even simpler. TIR: You did that in the "uncollected" section of Selected Poems.

DJ: I was using up what I knew about the blues in the two I included in the book and in four or five others I wrote at the same time but didn't publish. I may publish three or four more sometime, but ...

TIR: So you have more blues songs around.

DJ: Oh yes, but by now I've almost forgotten which lines come from traditional blues and which ones I've invented. I know they don't sound like Mississippi Delta blues, for instance, but then I didn't want them to, I'm not from the Mississippi Delta. I wanted them to be a sort of "literary blues." 
TIR: The blues lend themselves more to poetry because they have words built into them.

DJ: Yes, that's quite right.

TIR: And the sonatina is a much more abstract form.

DJ: Absolutely, but I do believe poetry is capable of being structured in terms that can be described abstractly. There may be half a dozen schools of theory which can't entertain that notion, but not to do so is an historical and esthetic blindness both. Obviously there is room for abstract structure in any esthetic design. There may be no necessity for it, but there is room for it.

TIR: But in the case of the sonatina you had some sense of that abstract structure when you began, while in other cases you may discover the structure along the way.

DJ: Actually I discovered the sonatina along the way too because although I knew what a musical sonatina was and I'd played many sonatinas on the piano, I didn't know what a sonatina in poetry would be until I had tried to write one. I don't think it turned out to be what I might ideally have imagined a literary sonatina to be, but it's similar. It's as close as I've been able to get, and I think it's as close as anybody's been able to get to a musical form in poetry-musical form, that is, so far as the structural outline goes.

TIR: The synesthesia in the titles mixes an aural form with a visual image; why did you add color to the musical structure?

DJ: Several reasons, but one was simply to emphasize the abstraction because the colors, musically speaking, must seem abstract. Actually in the text of the poems, there's very little reference to the color; it's background. There would be more reference to color in the prose commentary, but at least once in each of the poems, I think maybe only once, there's a reference to it. Yellow seemed to me eventually to associate with decay. And green with freshness. Not very original associations. The simple practical reason for the titles, however, was that I had bought in the university bookstore a four-color notebook to start writing the poems in, and one of the four colors was green and one was yellow, one was blue and one was pink. Pink was very hard; blue I almost managed, but not pink.

TIR: Is a "Sonatina in Blue" one of the sets of notes you're taking along?

DJ: No, I decided not to take it. I've given up on blue.

TIR: Are those five poems you're taking along new or old poems?

DJ: One goes back to the fall of ' 74 , the one I'm most serious about, but it's very hard and may end up rather long. It's in several parts and I've finished maybe two parts of it, or three. I don't know what will eventually become of it, but I must finish it. And the Tremayne poem I'm still working at I started in the fall of '77. That happened to be dated. All of these are failures, you might say, up to this point. They're poems I haven't been able to get right but that I have had some hopes for. 
The same with the plays. One of the plays I started in 1964 and I think the beginning of it is really very good, but it's hard to go on with.

TIR: Will the plays be easier to complete than the poems?

DJ: No, I don't think so. I know more about writing poems than I do about writing plays, so the poems really are easier.

TIR: Can you tell us something about the plays?

DJ: I don't think I should spoil them by talking too much about them. But I can say that one of them has to do with Lorca. One of the things I've done so far is to translate some Lorca poems not just into American but into what I think of as a sort of California language of the future. Not of the distant future, but if something like the death of Lorca were to occur in America, California would be the most likely place, wouldn't it? But that's enough on that, I think.

TIR: Another play you've been working on is an updating of The Tempest, isn't it?

DJ: Yes, right.

TIR: Is part of your updating that it's no longer verse drama at all?

DJ: What I've written of it is definitely not verse, it's prose. The updating amounted to a complete rethinking. The Tempest was going to be a kind of ideal model in the back of my mind which perhaps no one would ever think of in seeing the play. In the first version-it has now been changed a little-Caliban was going to be the second son of the Prospero character, and was going to be an auto mechanic by occupation and an amateur of the viola da gamba. It really should be Ariel, I guess, who plays this instrument, but I thought Caliban, who speaks so beautifully in the play- "This isle is full of noises"-ought to have it. Well, you know, I was just amusing myself by making false analogies.

TIR: Deflected analogies.

DJ: Yes, yes, that's better.

TIR: You do that all the time.

DJ: Well, yes, perhaps so. I don't know whether I'll be able to write these two plays or not but I'm going to try.

TIR: You mentioned four plays.

DJ: The other two are short, and whether anything will come of them or not I don't know. One is called "Faust: A Skit"-a farce, partly in verse. The other is called "The Whistler" and is about anti-Semitism.

TIR: These are subjects you would not feel like dealing with in poems?

DJ: I suppose not. Anti-Semitism, for instance. I don't know quite why, but early in life I was probably too much influenced by Poe's theory of poetry. Poems were not to be didactic, for example. I no longer think that's true, but I must have been affected by it.

I think poetry ought to be capable of dealing with anything. I mean, I do basically believe that. On the other hand, for me, it's very difficult to write a poem about something I could write an essay on. 
TIR: Maybe it's because in something like anti-Semitism there aren't many permissible views.

DJ: Well, the forbidden view has lately begun to become more and more permissible, apparently. Your point is a good one, but I think the unthinkable is becoming acceptable again, and I find that tragic, after the experience of the thirties and forties. This week I've been reading newspapers from the thirties because my wife happened to buy some from an antique dealer a few years ago. They're fascinating. One of the stories that keeps cropping up, on the front page of course, concerns whatever the latest decree of the Nazi government may have been. These decrees are treated just like ordinary news stories. And I remember how horrible it became. And the theme comes around again these days; it begins to matter a lot. Even so, I can't see myself writing a poem directly about it.

TIR: Can we return once more to "Sonatina in Yellow"?

DJ: Yes.

TIR: The epigraph is from Rilke, "Your quickly vanishing photograph in my more slowly vanishing hand." That strikes me as applicable to all your work. DJ: I think it might be.

TIR: It's applicable for a number of reasons, not the least of which is the reference to photographs. You've talked about poems at their best transmuting subjective experience into an object, and have said that that object at its best would be like a snapshot. It would be a memory captured that you could come back to and deal with because it's there now in an object.

DJ: I do believe that, yes.

TIR: The experience of many of your poems, for me, is the experience of reading a sensitive description of a snapshot or photograph, a photo that you care for greatly. I wonder how many of your poems actually are based on snapshots.

DJ: I don't think any of them are except the one I just finished, and even that wasn't a snapshot; it was a photograph by Walker Evans, a scene in Alabama in the thirties. I do carry around a packet of photographs of my parents and of houses we used to live in and that sort of thing. I've never been able to use them. You might say they have become for me a sort of talisman. I keep thinking they will fructify. But I don't think any poems I've written except this new one, are based on photographs. What they are based on, some of them, is memories of the way something looked at a certain time.

TIR: It's as if you were doing a photograph mentally, taking your own snapshot.

DJ: Yes, that's right.

TIR: So making the poem, then, is more like making a photograph than like describing one?

DJ: That's right. 
TIR: In "Memories of the Depression Years" there are three memories, at three-year intervals, and those are the snapshot-like moments that stand out? DJ: Yes, that's right.

TIR: Are there more that you're working on?

DJ: I certainly meant to write an endless series, but those were the only three I've managed to finish. I have no other notes on hand. I do mean to remain alert to the possibility of doing others that would fit into such a series, but I haven't got any.

TIR: Now that you've written a poem describing the Walker Evans photograph, what's the difference between writing that poem and creating the "photograph" or "snapshot" out of your memory?

DJ: I felt more limited in this case. I didn't want to depart from the facts of the photograph, which anybody else could look at too, and check up on. So I think the poem will seem esthetically cooler. I like to think that many of my poems seem objective and well-distanced, but I think this poem may be even more so. I was interested in it as practice, and indeed I've tried to write others; but I haven't been able to, and I've just about given up on the idea. I wanted to see what the answer would be to the question you just put to me, I think. I did not put as much of myself into it, and my own experience, though the scene was the kind of scene I recall from childhood.

TIR: I was going to ask what attracted you to the photograph. It was not a purely esthetic attraction.

DJ: No, it wasn't; it made a connection with my own life and the life of my relatives in the South in the thirties. I would like to be able to say, and it would be partly true, that it was like a photograph made of a long-ago part of my life.

TIR: This was a farm family?

DJ: No, it's a photograph sometimes identified as "Mule Team and Poster." It depicts a brick wall of what appears to be a warehouse. It's in Alabama in 1936, but I don't think it's in Let Us Now Praise Famous Men. It's just one of the Farm Security Administration photographs; it depicts a brick wall of what appears to be a warehouse in front of which a couple of mules are standing, munching corn shucks on the arid looking earth, and there's a poster of a Silas Green traveling show peeling from the wall. It's really quite beautiful, and I'm sure that one of my interests in it, one of the secrets of its appeal to me, was that the manifest content of the photograph was ugly and unpleasant-and I myself knew that ugliness and unpleasantness because I had been in Alabama in 1936, and in the summertime, and it really was like a photograph of something I could almost remember. My father was from Alabama, farther south than where this photograph was made, and we used to visit our relatives over there, poor farmers and store clerks and so on. There seemed to be a lot of this sort of thing-brick walls and mules standing in front of them, and 
posters advertising movies of traveling shows. Out of this very unattractive but quite sympathetic scene, an arrangement of great beauty, I thought, and evident art had come forth, through Evans. Art having occurred, I wanted to try to multiply that art.

And then, last week I spent trying to describe another Evans photograph and wasn't able to.

TIR: What do you mean? That you found that what you thought to say about it just doesn't interest you once it's said?

DJ: In part. I simply was not able to see enough in the photograph to make saying so much worthwhile. The words were not paying off with a high enough quotient of what Aristotle would have called "thought"- what I call "perception." So it just wasn't worth it. I could describe the thing perfectly well, in a somewhat heavy style, as luck would have it, but once I'd done that, it didn't make any difference. It didn't make enough difference. With the first of Evans' photgraphs I judged, maybe wrongly, that I had seen enough in it to make the saying count.

TIR: Had your father grown up on a farm in Alabama?

DJ: Yes, he had been born in southern Alabama and then as a youth he moved over to a part of Georgia adjoining Alabama and which looked just like it as far as I could tell. This was a part of my summers growing up, not a part I really liked.

TIR: Are you aware much of generations beyond, say, your grandfather? DJ: Not much beyond great-grandfathers, no. I can't account for it, perhaps because we were always poor, but on neither side of my family do recollections go back beyond what would be my great-grandparents-except for a story about a woman ancestor on my father's side who became a stowaway to North Carolina supposedly because she had committed some technical offense against a king or a king's property, a king's forest perhaps. Maybe she poached. But those stories grow to be a little like myths; you don't know how much to credit them. And there aren't many such stories in my family, unhappily. I wish there were.

TIR: Have you always been fascinated with family albums and looking at pictures?

DJ: I didn't know that I was, but I was; my mother was, and she thrust them upon me from the start.

TIR: When you were working on the Evans photograph, did you think of Williams' Pictures from Brueghel?

DJ: Absolutely. It would be awfully hard not to. I once tried writing a series of poems on Hopper paintings and they sounded like Williams' Brueghel poems, but defective somehow. Yes, the Williams poems are very powerful; it would be hard to resist them. But I tried to, not quite successfully. TIR: It's interesting that your memory leads to repositories of lore like family 
albums or the attic (as in "In the Attic" and "Fragments") whereas the more popular American metaphor for examining the past is digging in earth. Archaeological excavations, roots, seem more the cliches of our time.

DJ: I hadn't thought of that. I don't know what that means. If you grew up in South Florida as I did, houses had no attics. Or very few houses had attics. If you went to visit a relative somewhat farther north there might be an attic, and you might go up into it. It would have been a privileged place-a repository of the really rather distant past, you know, of strange, exciting objects. Many children must have felt that. I don't think the attic fails to be a kind of cliché too, for a place the past has been left in. Roots may be a more active and dramatic metaphor, but I hadn't thought of the contrast.

TIR: The attic is the image of the family past.

DJ: That's right.

TIR: As opposed to roots and the archaelogical past, the tribal past.

DJ: Right, and what I write about, I guess, is narrower than archaeology, tribes, and all that. What I can think about seems more limited.

TIR: It's personally associated memory rather than historically or pre-historically associated memory.

DJ: I couldn't write about bog men, for example, like Heaney. I just can't imagine bog men.

TIR: But he lives around bogs.

DJ: All right, and I don't so I musn't write about bog men.

TIR: But we could conceivably write about the Hopewell or the Effigy Mound Builders.

DJ: If we'd taken part in the digging, perhaps.

TIR: There's another kind of memory alive in your poems, that being the memory of a spacious poetic past. In "Ladies by their Windows," which opens Selected Poems, you write, "It is the lurch and slur the world makes, turning./ It is the sound of turning, of a wheel/ Or hand-cranked grinder turning." I hear an echo from Conrad Aiken's "Sound of Breaking," where he says "It is a sound of breaking,/ The world is breaking, the world is a sound of breaking." There are frequent echoes of this kind in your poems. Did you intend this one?

DJ: I was aware when writing it of that one and yet in all the years since no one, till now, has ever mentioned the Aiken poem to me. I'm pleased that you know it. Yes, I discovered that poem when I was about fifteen, I think, at least I remember the summer, reading it on my grandfather's porch. I've always liked it, and I was not sorry to echo it if it could be done gracefully.

TIR: Do you find Aiken helpful in other ways?

DJ: No, I'm afraid not.

TIR: I ask because as I was looking up that poem to hear exactly the lines I was hearing in your poem ... 
DJ: It was the sound that I was after, the sound.

TIR: I came across "Senlin."

DJ: That was a poem I knew, definitely.

TIR: I was fascinated because when I read the Tremayne poems again after reading "Senlin," I thought of them as similar types of character.

DJ: Maybe as types of character, but I would think the Tremayne poems had more in common with Robinson or perhaps Hardy than with Aiken. Aiken is smoother, the edges are more shorn off. Maybe I'm wrong, but the poems of his that I remember from the period I liked most in him impressed me with their beautiful smoothness. I was unable to write smoothly then. It really is easy once you get the knack of it, but when you don't have that knack, smoothness may come to seem like an overpowering virtue.

Also, when I was young, I was interested in writing very elaborate syntax. Some of the poets I liked a lot were interesting in part because of their syntax. Yeats sometimes has a very elaborate syntax. And I wanted to try that. Even Williams, though he looks simple, has a very elaborate syntax, and this challenged me. But then at some point comes the desire to purify, to simplify, and that has, you know, begun to appeal to me more and more.

One of the things that interests me syntactically now is the use of fragments, as in the last line of "Thinking about the Past," which goes "Dusks, dawns; waves; the ends of songs..." I don't know that anybody else likes or ought to like that, but I like the line myself and in part because it's just like little bits of consciousness floating up. Touches of a brush, say. It seems to me that fragments sometimes can have that effect. The first time I recall really liking fragments myself and seeing more powerful possibilites in them was in reading Alberti, who uses fragments beautifully, dramatically. Ever since I've tried to do something with them. Of course I don't at all mean the notational style you see frequently, ever since the Imagists at least, and not only in amateur verses-as if to suppress a verb were to write a line.

TIR: Whether we're talking about elaborate or simplified syntax, or about fragments for that matter, we're talking about kinds of technical proficiency. DJ: Yes, there are properties which, I think, belong unarguably to poetry, and one of them is technical virtue. I don't know how else to put that, but without it poetry dies. I think, on the other hand, poetry can live on the strength of technical virtue alone, but it only lives a sort of half life then, like much of Aiken, which I regard as quite beautiful but not whole. When you write, you have to be willing to settle for that, I think, but what you really desire is something whole; large, even. Aiken wanted that too, I'm sure, it's just that he was probably best when he concentrated on lesser goals. A number of poets have been best when they weren't trying too hard.

Poetry at its best, is fulfilling its nature most entirely, when it has a great mastery of form, or technique, and shows considerable, though perhaps a 
hidden or disguised interest in its own formal or technical character. Otherwise it might as well be prose. I love prose, and it really might as well be prose. Now once it has this, it is of course much better if what is said proves interesting and intelligent and intelligible and true and perceptive and has all those virtues one would expect even of expository prose. And of course it becomes even better if the themes it deals with are grand. A seven-line poem ought to be better than a six-line poem, all other things being equal, simply because it contains more. But all those things are not equal, and what is basic and absolutely necessary is formal and technical character; otherwise the poem will be forgotten eventually, or remembered only for something like the personality or history of the poet, or the fact that he may have been the first or the loudest to deal with a certain topic, or something of that sort. Well, that is of a certain interest, too. I don't wish to deny it. But for the art of poetry itself, basic is some formal or technical interest. That does not mean that anyone can or should prescribe the nature of that formal or technical interest in advance of the occasion. That always remains to be defined, or ought always to remain to be defined, for the various occasions, and by the age. But I think it is absolutely essential.

TIR: Many poets today would say that memory seeks out its own meter, but in a very real way, with you, meter seeks out memory, right?

DJ: Well, I'm willing to go with that version, though it seems an extreme way of putting it.

TIR: It's an extreme reversal, but you've talked about meter as a kind of substantiation of your poetry, even as a "fixative" of memory.

DJ: If you're working in meter in the first place-you don't have to work in meters, in the kind of meters I'm thinking of-but if you are, then to get it wrong proves to you that you haven't even, as I would suggest, remembered it right. If you commit yourself, if you give yourself over to the meters, they have to be right. If you don't, well, that's a different story.

TIR: If we think less of meters than of form, much the same thing applies. In "Sonatina in Yellow," you hadn't been seeking out a way to talk about your father in a particular form, but the form you devised gave you the memory of your father.

DJ: In a sense that's true, yes. It is a false notion, I am sure, to propose that poetry comes only from subject, is never more than an extension of content, as one might say. Poetry comes from anywhere, and the subject is certainly a major source, probably the major source. If you have something you care a lot about, then you may well write a poem about it, may indeed be driven to do so. But it can come from elsewhere-just as a composition in music may come from merely fooling around. Or from thinking: This time I'll try D minor; or, I like what Handel wrote just there, I think I'll try some variations on it. It comes from anywhere, and as far as I'm concerned, there should be 
no hierarchy of values in the consideration of this. What matters is the result, not the source, the origin, or the theory.

TIR: Your history so far seems to suggest a particular interest in seeking conscious deflections from established forms. I'd see that interest in deflection as central, as you say, to the "formal or technical character" of your work. DJ: I would like to think so.

TIR: In "Variation for Two Pianos," for example, were you thinking of the villanelle when you started the poem?

DJ: Of course.

TIR: And simultaneously thinking of not doing the villanelle.

DJ: Yes, exactly. The villanelle is practically impossible, at least in English, and I don't know of any villanelle that doesn't have at least one waste stanza in it. There seems to me no obligation to carry on with a proper villanelle when it may mean including one or two stanzas less good than the others. So you may end up with a quasi- or pseudo-villanelle if you're going to do one, unless you happen to be very lucky and get the whole thing. A double villanelle, even. I can imagine that, but it would be hard to find.

TIR: What do you mean by "get" and "find"?

DJ: "Find" may be the better word for it. I mean something like going on a voyage of discovery in the old days, or prospecting, digging for precious metals. TIR: The sestinas are another example; they avoid the usual sestina metrics. DJ: When I was writing those sestinas, I think all the sestinas that had been written in English before, all that I had read anyway, were in iambic pentameter-or at least in what I would call a casual pentameter, one in which the line might get a little longer or a little shorter, as in Pound's or the two by Kees. But I consciously shortened the lines; I varied the length of the lines. Nowadays anybody may do that. The Katmandu sestina has a small place in the history of the form, I think.

TIR: I want to get to your "Odes" in a moment but by way of "Elsewheres." That seems to be a more sophisticated deflection. "North," "South," "Waiting Room," that's not ...

DJ: It should be the Midwest, say, or the middle of something anyway, right? TIR: You mentioned the checkered fields of the Midwest in that, but that was another attempt, I take it, not to be satisfied with the symmetry you would expect-North and South-but to get outside of it.

DJ: That's right.

TIR: In addition to specific deflected forms, groups of your poems sometimes deny expectations of patterns. In the gathering of three odes, for example, the "Cool Dark Ode" addresses night and suggests winter night; the "Warm Flesh-Colored Ode" suggests late summer. But what does the "Pale Tepid Ode" suggest? You set up a pattern, then jump track.

DJ: Well, on the other hand, it keeps to the track because you have "Cool Dark," "Warm Flesh-Colored" and what's left? Not much. 
TIR: You reverse the placement of the adjectives-"Pale Tepid" rather than "Tepid Pale."

DJ: But that's the way it would be in speech probably; you wouldn't say "tepid pale." If you did it would be like the overcareful Joycean placement of adjectives before a noun. It's just something other than the two that come before it-what's left? That's the way I thought of it. Sort of the bleaching out of colors, of definition. I don't know how to put it, but it seemed to me altogether obvious that "Pale Tepid" followed from "Cool Dark" and "Warm Flesh-Colored." Just set yourself that problem. What pair of adjectives having to do with color and temperature could possibly come next?

TIR: Well, given cool and warm, you'd have to say something like ...

DJ: Lukewarm anyway, or pale, or tepid, or ...

TIR: Terribly hot.

DJ: Sure, but that's not my style.

TIR: I'm fascinated that you say it seemed perfectly natural that that would be the completion. I think it's not perfectly natural to most people.

DJ: All right, okay, but I'm asking, well, "terribly hot," yes, all right. But what color? After dark and flesh-colored. If you had to have a third.

TIR: Well, "flesh-colored" seems mild. I might think of something harsh, say, "dazzling.",

DJ: "Dazzling" might be good. I may write a fourth, "Hot Dazzling Ode." TIR: If you do, you owe that one to us.

DJ: I do indeed. But look, one reason I like series and groups is because once you have a couple of poems connecting somewhere or associating in some way, another may be produced simply by thinking: What would be related, what would come out of, or what would connect with that? Anybody becomes inventive thinking along those lines.

TIR: I'm thinking of a pattern suggested by "Unflushed Urinals" and "Sunday Afternoon in Buffalo, Texas."

DJ: I consider the Walker Evans poem I spoke of as a third along those lines. They're American scenes, and I really feel I should take a couple more bus trips and see what turns up.

TIR: It has to be by bus?

DJ: Well, it seems so. The bus still shows you the America of the past. Plane rides, in this respect, don't seem to turn up anything. One of the great experiences of my married life was to take the bus from Albemarle, North Carolina to Palo Alto, California years ago. It was an awful and wonderful experience. Four nights and three days, or three nights and four days; I've forgotten which. And we'll never forget that trip.

TIR: Speaking of things American, do you see an American tradition that has influenced your own work, an American tradition in poetry that you look back toward? 
DJ: I can say whom and what I like, that's about all. In America there is not just one line of evolution, one stream, despite the propoganda. As for American poets of the nineteenth century, I like Emerson; I think he's a good poet, and I like some of Melville's poems. I like Emily Dickinson very much; I think she's a very great poet. I like Trumbull Stickney; Tuckerman. And I respect Whitman, without having the kind of affection for him many people seem to have. The twentieth century begins for me with Edwin Arlington Robinson. And in this century the best poets seem so different from one another that any attempt to define an American tradition ought to involve some strong sense of the variety and the diversity and the going off in all directions. Emerson does not necessarily end up in James Dickey.

TIR: Hart Crane?

DJ: Hart Crane is a master, yes, in a few lines anyway. Such beauty as I hope not to be forgotten.

TIR: Ezra Pound?

DJ: Early Pound anyway, yes, a master. Thereafter, I don't know. Thereafter I think he became victimized, as far as I can tell, by ideas. As Emerson might have put it, "Ideas are in the saddle and ride mankind." When that happens with poetry, something goes wrong, I believe, and I believe that happened to Pound. I know that not everyone thinks so, in fact most people probably don't. But just reading him for pleasure and the power of invention or recovery, for the beauty of sound and the shapeliness of his expression, the early poems seem certainly very fine-Personae, including of course Cathay.

TIR: Which of the American poets do you find yourself returning to and reading most?

DJ: Williams would be among them, certainly. Williams is so inventive, and he does hold up. Stevens of course is another. Eliot remains for me a great model of seriousness. His ideas are another matter, but ... Well, let's see, Robinson I read frequently with pleasure, and Emily Dickinson. I shouldn't forget Frost, for years my favorite. Those are, I think, the main ones.

TIR: Do you subscribe to the separation of the Dickinson and Whitman traditions?

DJ: If it's forced upon me, I do. If there were an election in November, I'd go with Dickinson, the one with the more modest scope.

TIR: I sometimes hear Dickinson off-rhymes in your poetry.

DJ: Maybe so; I think off-rhymes can be very nice, but they may have come as much from incapacity as from remembering Dickinson.

TIR: Ransom, Tate, Warren?

DJ: Yes, I haven't gone back and read them lately, but they certainly were a formative influence. I wrote my master's thesis on them, and in a way I've always known their work. Ransom is a favorite.

TIR: You mentioned once that the first poet of note that you heard read was Robert Frost. 
DJ: I don't think other poets were reading much in public then. I lived and went to school in Miami where he wintered in the early forties, and he would read at the university. He would say at the end of a reading, "Now what are your favorites, what would you like to hear?" That used to embarrass me. I was studying composition with a composer named Carl Ruggles. At one of those readings, maybe the very first one I went to, Ruggles-who also came down from New England to winter there and who knew Frost-called up one of his favorites and I felt terribly embarrassed for those two great men. It seemed to me, in my juvenile way, not sophisticated. Come to think of it, it still does.

TIR: What about the European poets? Obviously the French and Spanish poets. DJ: Mainly them; I don't really read any foreign language with great ease, and certainly I don't speak any. Those are the two that I know best. I worked hard to get acquainted with some poetry in German, postwar poetry, but French and Spanish I feel a little more comfortable with.

TIR: Is Alberti the master in that group for you?

DJ: Absolutely.

TIR: South American poets?

DJ: Oh yes, well, my favorite American poet in Spanish is a Mexican poet, Ramon López Velarde.

TIR: I don't know of him at all.

DJ: Paz calls him the father of Mexican poetry. He died about the time the First World War ended, at an early age, but I think he's a very great poet. H. R. Hays translated some of his poems during the Second World War, and he's been intermittently translated since, but there's never been a collection of translations and there should be; he's very good.

TIR: Let's go back to the Anglo-American poets briefly. When you go back to Williams, which periods or volumes do you favor?

DJ: Well, there are two moments in his career that I particularly like. One is the Spring and All period, 1922 or thereabouts. The other is the Pictures from Brueghel period, postwar, indeed post-Paterson. For me those are the two most moving and instructive passages in his career. I like the historical book, In the American Grain, I like much of that very well indeed. The novels have not grabbed me; a few stories. I think he was a major figure in the twentieth century, perhaps in spite of himself.

TIR: With your interest in meter and measure, how do you react to Williams' emphasis on measure, on finding an American measure, and his attempts to break a Whitman line into three parts, to put the Whitman line into a proper measure, his creation of the variable foot, and so on?

DJ: Well, very simply and with great respect for Williams, it's this: that his theories about meter are interesting because he writes meters, not because he writes about meters. I think that he writes, when he writes critically, too confusingly, too vaguely, which he does not do when he's writing poems. 
TIR: The direct influence of Williams on your work would be seen in "American Sketches."

DJ: I was trying to perform a sort of hommage to Williams there, but I wouldn't be surprised if I could show ...

TIR: I would think in these snapshot-like pieces, too.

DJ: Maybe. What I think happens is that, say, X turns something up, but it really doesn't belong to him or her; it's something that's in the culture, and you are free to deal with it, to try your hand at it too, I think, without becoming an epigone. Now there have been epigones of Williams, but that's a different story.

TIR: You wouldn't be mistaken for one of those.

DJ: To tell the truth, I don't think that he would have liked me, but that doesn't matter.

TIR: He's the one of that generation you read the most.

DJ: If I'm looking to learn something, yes, and next to him Stevens. Stevens would be a close second. They are very different, even though they were friends of a sort.

TIR: Marianne Moore?

DJ: I read her, but I prefer Elizabeth Bishop. I would think that Elizabeth Bishop is Marianne Moore perfected. On the other hand something must be said for Moore because she was in this vein the pioneer. I like reading them both actually, but seeing things historically is important, I believe, for the writer. I have students who don't think so, who think everything was all written at about the same time, usually yesterday. I think it is interesting to know that Elizabeth Bishop comes after Marianne Moore, if only for the sake of accuracy and historical truth. But also for the evolution of an art; the changes, aside from their intrinsic interest, cannot fail to show you something about your own work if you're willing to learn.

TIR: That brings us back to Selected Poems and why it's in "fair chronological order."

DJ: Well, I did some things after other writers and some things before other writers and this ought to lay out the record of which was which. For those who care. 